\title{
Front Matter: Volume 11901
}

, "Front Matter: Volume 11901," Proc. SPIE 11901, Advanced Sensor Systems and Applications XI, 1190101 (15 November 2021); doi: 10.1117/12.2619266

SPIE. Event: SPIE/COS Photonics Asia, 2021, Nantong, Jiangsu, China 


\title{
PROCEEDINGS OF SPIE
}

\section{Advanced Sensor Systems and Applications XI}

\author{
Zuyuan He \\ Gang-Ding Peng \\ Editors
}

\section{0-12 October 2021 Nantong, China}

\author{
Sponsored by \\ SPIE \\ COS-Chinese Optical Society
}

\section{Cooperating Organizations}

Tsinghua University (China) - Peking University (China) • University of Science and Technology of China (China) • Zhejiang University (China) • Tianjin University (China) Beijing Institute of Technology (China) • Beijing University of Posts and Telecommunications (China) - Nankai University (China) - Changchun University of Science and Technology (China) - University of Shanghai for Science and Technology (China) • Capital Normal University (China) - Huazhong University of Science and Technology (China) • Beijing Jiaotong University (China) - China Jiliang University (China) - Shanghai Institute of Optics and Fine Mechanics, CAS (China) - Changchun Institute of Optics, Fine Mechanics and Physics, CAS (China) - Institute of Semiconductors, CAS (China) - Institute of Optics and Electronics, CAS (China) - Institute of Physics, CAS (China) Shanghai Institute of Technical Physics, CAS (China) • China Instrument and Control Society (China) The Optical Society of Japan (Japan) • Optical Society of Korea (Korea, Republic of) - Australia and New Zealand Optical Society (Australia) - Optics and Photonics Society of Singapore (Singapore) - European Optical Society

\section{Supporting Organizations}

China Association for Science and Technology (CAST) (China) - Department of Information of National Nature Science Foundation, China (NSFC) (China)

\section{Published by}

SPIE 
The papers in this volume were part of the technical conference cited on the cover and title page. Papers were selected and subject to review by the editors and conference program committee. Some conference presentations may not be available for publication. Additional papers and presentation recordings may be available online in the SPIE Digital Library at SPIEDigitalLibrary.org.

The papers reflect the work and thoughts of the authors and are published herein as submitted. The publisher is not responsible for the validity of the information or for any outcomes resulting from reliance thereon.

Please use the following format to cite material from these proceedings:

Author(s), "Title of Paper," in Advanced Sensor Systems and Applications XI, edited by Zuyuan He, Gang-Ding Peng, Proc. of SPIE 11901, Seven-digit Article CID Number (DD/MM/YYYY); (DOI URL).

ISSN: 0277-786X

ISSN: 1996-756X (electronic)

ISBN: 9781510646513

ISBN: 9781510646520 (electronic)

Published by

SPIE

P.O. Box 10, Bellingham, Washington 98227-0010 USA

Telephone +1 3606763290 (Pacific Time)

SPIE.org

Copyright (C) 2021 Society of Photo-Optical Instrumentation Engineers (SPIE).

Copying of material in this book for internal or personal use, or for the internal or personal use of specific clients, beyond the fair use provisions granted by the U.S. Copyright Law is authorized by SPIE subject to payment of fees. To obtain permission to use and share articles in this volume, visit Copyright Clearance Center at copyright.com. Other copying for republication, resale, advertising or promotion, or any form of systematic or multiple reproduction of any material in this book is prohibited except with permission in writing from the publisher.

Printed in the United States of America by Curran Associates, Inc., under license from SPIE.

Publication of record for individual papers is online in the SPIE Digital Library.

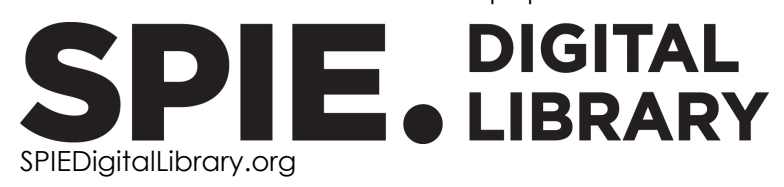

Paper Numbering: A unique citation identifier (CID) number is assigned to each article in the Proceedings of SPIE at the time of publication. Utilization of CIDs allows articles to be fully citable as soon as they are published online, and connects the same identifier to all online and print versions of the publication. SPIE uses a seven-digit CID article numbering system structured as follows:

- The first five digits correspond to the SPIE volume number.

- The last two digits indicate publication order within the volume using a Base 36 numbering system employing both numerals and letters. These two-number sets start with $00,01,02,03,04$, 05, 06, 07, 08, 09, OA, OB ... 0Z, followed by 10-1Z, 20-2Z, etc. The CID Number appears on each page of the manuscript. 


\section{Contents}

BIOLOGICAL AND CHEMICAL SENSORS I

1190102 Cryogenic temperature sensor based on an optical fiber Fabry-Perot interferometer with high sensitivity (Invited Paper) [11901-1]

1190103 Fiber-laser-enhanced WGM microtubule cavity for myocardial infarction biomarker detection [11901-2]

1190104 Feasibility assessment of an optical sensor for long-term electrocardiogram monitoring [11901-5]

MECHANICAL AND ELECTRICAL SENSORS

1190105 Analysis of fabrication error and optimization technique of $\lambda / 4$ waveplate for fiber optical current transformer (Invited Paper) [11901-6]

1190106 Design and simulation analysis of fiber optic current sensor using orbital angular momentum beam [1 1901-7]

1190107 Research on the Shupe effect error caused by asymmetry of the dual 90-degree rotation splices in the resonator of the resonant fiber optic gyroscope [1 1901-8]

1190108 A sensitivity-enhanced all-fiber Fabry-Perot high-pressure sensor with a hard-core diaphragm [11901-9]

1190109 Methods for measuring angular velocity based on the use of optical parity-time-symmetry systems [11901-10]

\section{MICROSTRUCTURE SENSORS AND SPECIALTY FIBERS}

11901 OB Fiber-optic airflow sensor for air quantity estimation in air conduit [1 1901-14]

11901 OC High sensitivity distributed static strain sensing based on all grating optical fiber in optical frequency domain reflectometry [11901-15]

\section{BIOLOGICAL AND CHEMICAL SENSORS II}

11901 OD Highly sensitive temperature sensor with optomechanofluidic resonators (Invited Paper) [11901-16] 
11901 OF Optical fiber probe for CARS spectroscopy [11901-18]

$119010 G$ Simultaneous measurement of refractive index and temperature based on bent core-offset inline fiber Mach-Zehnder interferometer [11901-19]

$11901 \mathrm{OH} \quad$ Broad-range self-sweeping Ho-doped fiber laser for $\mathbf{N}_{2} \mathrm{O}$ spectroscopy tasks [11901-20]

\section{NEW SENSOR DEVICES AND SYSTEMS}

119010 Semiconductor optical amplifier fiber-ring laser for FBG dynamic strain sensing with an adaptive two-wave mixing demodulator [11901-21]

11901 OK Bandwidth evaluation of $11 \mathrm{~cm}$-long polymer waveguides based on optical sampling technique [1 1901-23]

11901 OL Changes in speckle patterns in an output light spot from an optical fiber to be caused by load application of small weight level (Invited Paper) [11901-24]

11901 OM Automatic control of the tuning parameters of a self-sweeping Tm-doped fiber laser [1 1901-25]

\section{NEW SENSOR TECHNIQUES AND APPLICATIONS}

$119010 \mathrm{~N} \quad$ Ultrasonic optical fiber sensing for composite structural health monitoring (Invited Paper) [11901-26]

1190100 Measurement of linewidth enhancement factor based on self-mixing interferometry and back propagation neural network [11901-27]

11901 OP Sensing interrogation system with Michelson interferometer incorporating an optoelectronic oscillator [11901-28]

$119010 Q \quad$ Orthogonal phase demodulation system with wide frequency band response based on birefringent crystals and polarization technology [11901-29]

11901 OR Dynamic speckle analysis using the event-based block matching algorithm [1 1901-30]

\section{POSTER SESSION}

11901 OS Analytical solutions for polarization mode dispersion and decorrelation in optical fibers with weak random varying birefringence [11901-13]

11901 OT A fiber-optic sensing system based on broadband light source carried microwave interferometry [11901-31]

iv 
11901 OU Study of a liquid level sensor based on a tilted long period grating imprinted on a plastic optical fiber [11901-32]

$119010 \mathrm{~V}$ Investigating the properties of self-standing nickle-mesh decorated with Au nanoparticles for flexible transparent $\mathrm{H}_{2} \mathrm{O}_{2}$ sensor [11901-35]

11901 OW Solutions on multiple configuration sensing systems [1 1901-36]

11901 OY Detection of $\mathrm{SO}_{2} \mathrm{~F}_{2}$ concentration of $\mathrm{SF}_{6}$ decomposition product in GIS gas chamber based on ICL-TDLAS [11901-38]

1190111 Sensitivity analysis of fault detection for few-mode fiber links based on Rayleigh backscattering [11901-41]

1190113 Measurement of damping vibration using self-mixing interferometry under strong feedback regime [1 1901-43]

1190115 A distributed optical fiber temperature measuring system for oil wells [1 1901-45]

1190116 Magnetic field sensor based on Terfenol-D coated optical fibers [11901-46]

1190117 Characteristics of partially coherent laser field backscattered by atmospheric aerosols [11901-48]

1190118 Suppressing interference fading in $\Phi$-OTDR with intensity-coded pulse based on spectrumextraction and rotated-vector-sum method [11901-49] 
Proc. of SPIE Vol. 11901 1190101-6

\section{Downloaded From: https://www.spiedigitallibrary.org/conference-proceedings-of-spie on 25 Apr 2023
Terms of Use: https://www.spiedigitallibrary.org/terms-of-use}

